\title{
USLUGI KSIĘGOWO-PODATKOWE ON-LINE JAKO ALTERNATYWA DLA TRADYCYJNEGO BIURA RACHUNKOWEGO
}

\section{Wstęp}

Przedsiębiorcy w Polsce zobowiązani są do tworzenia dokumentacji zawieranych transakcji, a także dokonywania rozliczeń z Urzędem Skarbowym oraz Zakładem Ubezpieczeń Społecznych. Zasady rozliczenia uzależnione są od wielu czynników, m.in. od wielkości prowadzonej działalności gospodarczej. Mając na względzie problem podniesiony w niniejszym artykule, uwaga autorki została skupiona na najmniejszych podmiotach gospodarczych, gdyż są oni głównymi odbiorcami usług księgowo-podatkowych on-line. Mikroprzedsiębiorcę ${ }^{1}$ często nie jest stać na zlecenie usług księgowo-podatkowych biuru rachunkowemu i szuka sposobu na tanie prowadzenie księgowości swojego podmiotu. Decyduje się na zatrudnienie księgowej w oparciu o umowę zlecenie lub sam próbuje własnych sił $\mathrm{w}$ księgowości. W przeciągu ostatnich kilku lat nową propozycją $\mathrm{w}$ zakresie prowadzenia ksiąg podatkowych ${ }^{2}$, dla małych jednostek gospodarczych, są usługi księgowo-podatkowych świadczone on-line.

\footnotetext{
* Doktorantka, Katedra Rachunkowości, Wydział Zarządzania, UŁ.

${ }^{1}$ Mikroprzedsiębiorca jest to przedsiębiorca, który w co najmniej jednym z dwóch ostatnich lat obrotowych: zatrudniał średniorocznie mniej niż 10 pracowników oraz osiągnął roczny obrót netto ze sprzedaży towarów, wyrobów i usług oraz operacji finansowych nieprzekraczający równowartości w złotych 2 mln euro lub sumy aktywów jego bilansu sporządzonego na koniec jednego z tych lat nie przekroczyły równowartości w złotych 2 mln euro. Przy czym:

- wyrażone w euro wielkości przelicza się na złote według średniego kursu ogłaszanego przez Narodowy Bank Polski w ostatnim dniu roku obrotowego wybranego do określenia statusu przedsiębiorcy,

- średnioroczne zatrudnienie określa się w przeliczeniu na pełne etaty,

- przy obliczaniu średniorocznego zatrudnienia nie uwzględnia się pracowników przebywających na urlopach macierzyńskich i wychowawczych, a także zatrudnionych w celu przygotowania zawodowego,

w przypadku przedsiębiorcy działającego krócej niż rok, jego przewidywany obrót netto ze sprzedaży towarów, wyrobów i usług oraz operacji finansowych, a także średnioroczne zatrudnienie oszacowuje się na podstawie danych za ostatni okres, udokumentowany przez przedsiębiorcę (Ustawie o swobodzie działalności z 2 lipca 2004 r. (Dz.U. 2004, nr 173, poz. 1807, art. 104, 107, 109).

${ }^{2} \mathrm{~W}$ art. 3 ust. 4 zamieszczono definicję pojęcia „księga podatkowa”, a w zasadzie „zbiór ksiąg podatkowych", do którego zaliczono: księgi rachunkowe, podatkową księgę przychodów i rozchodów oraz ewidencje i rejestry, do których prowadzenia na podstawie odrębnych przepisów są
} 
Przenoszenie do Internetu pracochłonnych i kosztownych obszarów działalności przedsiębiorstwa staję się coraz bardziej opłacalne. Jak podaje Konferencja Narodów Zjednoczonych do Spraw Handlu i Rozwoju UNCTAD, znakomita większość światowego wzrostu gospodarczego ma związek z Internetem³

\section{Zakres i metodyka badań}

Niniejsze opracowanie poświęcone jest nowoczesnym rozwiązaniom towarzyszącym prowadzeniu ksiąg rachunkowych w postaci usług księgowopodatkowych on-line. Metodami służącymi do realizacji celu artykułu były przede wszystkim: wnikliwa analiza zgromadzonej literatury oraz studium przypadku jednostki zajmującej się usługami on-line z zakresu księgowości i podatków.

$\mathrm{Z}$ uwagi na fakt, iż usługi księgowo-podatkowe on-line są relatywnie nowym zagadnieniem w Polsce, nadal występuje niewiele opracowań w literaturze przedmiotu na ten temat. W związku z tym autorka korzystała głównie $\mathrm{z}$ artykułów publikowanych w literaturze praktyków oraz na konferencjach naukowych.

Studium przypadku (case study) jest natomiast metodą badania, w której autorka dążyła do wszechstronnego opisu jednostki z uwzględnieniem zarówno bogatego zestawu zmiennych, jak i zależności między nimi. Analiza przypadku polegała przede wszystkim na analizowaniu i omawianiu prawdziwych sytuacji. Popularność tej metody ma na celu wprowadzenie realizmu do pracy badawczej. Pozwala integrować wiedzę praktyczną z wiedzą teoretyczną i pokazuje zależności pomiędzy nimi. Pod względem celów i procedur metoda studium przypad$\mathrm{ku}$ przypomina badanie naukowe. $\mathrm{Z}$ drugiej strony jest to metoda na tyle nieformalna, że dopuszcza wyciąganie wniosków adekwatnych do konkretnie rozpatrywanego przypadku, nie zaś odnosząca się do ogółu populacji ${ }^{4}$.

Tworząc studium przypadku, autorka zastosowała obserwację uczestniczącą i tym samym została outsourcingobiorcą usług księgowo-podatkowych on-line w okresie stycznia-marca 2013 r. W tym czasie na portalu spółki A prowadzono podatkową księgę przychodów i rozchodów, poznając badane zagadnienie z perspektywy klienta.

obowiązani podatnicy, płatnicy i inkasenci (ustawa z 29 sierpnia 1997 r. Ordynacja podatkowa (Dz.U. 1997, nr 137, poz. 926, z późn. zm.).

${ }^{3}$ Firmy tna koszty i przechodza na e-Księgowość, http://finanse.wp.pl (dostęp 26.03.2013).

${ }^{4}$ K. Budzik, Metody badań empirycznych, [w:] Strzyżewska M. (red.), Doktoranci o przygotowaniu konspektu pracy doktorskiej, Szkoła Główna Handlowa Oficyna Wydawnicza, Warszawa 2007, s. $142-143$. 


\section{Istota usług księgowo-podatkowych on-line}

Usługi księgowo-podatkowych on-line, zwane przez praktyków także księgowością internetową, e-księgowością czy księgowością on-line, to nowoczesny sposób usługowego prowadzenia ksiąg podatkowych, który umożliwia łatwe i tanie przetwarzanie danych księgowych obejmujące całość prac ewidencyjnych, rachunku kosztów i sprawozdawczości. Polega na udostępnieniu klientowi przez outsourcera - biuro rachunkowe systemu informatycznego - zasobów kadrowych oraz wiedzy merytorycznej dla bieżącej realizacji potrzeb w zakresie ewidencji oraz informacji księgowo-podatkowej. Ogólny schemat świadczenia usług księgowo-podatkowych on-line ilustruje rysunek 1.

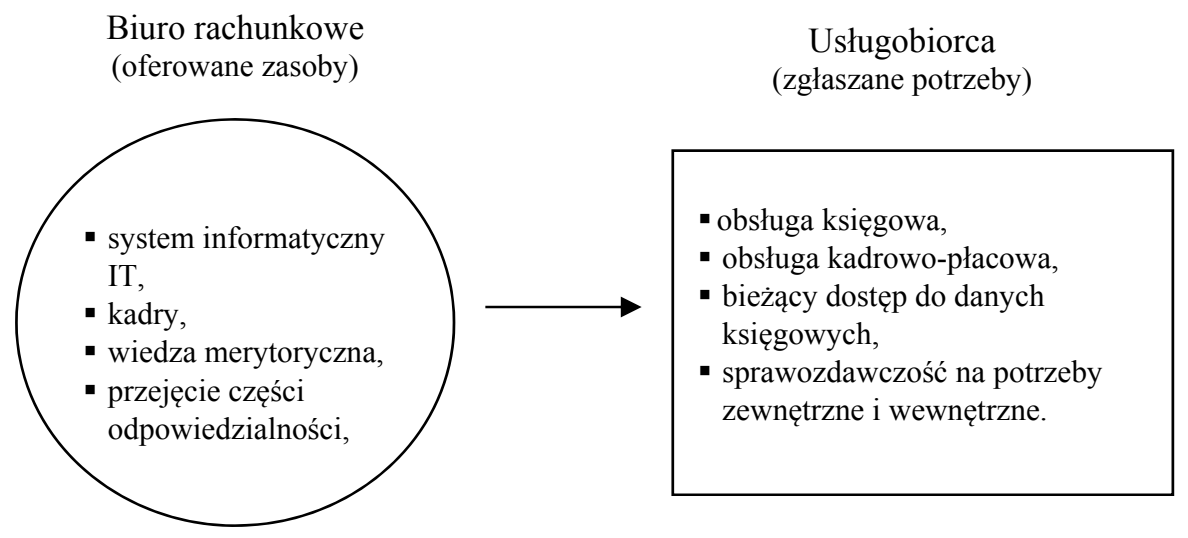

Rysunek 1. Ogólny schemat świadczenia usług księgowo-podatkowych on-line

Źródło: opracowanie na podstawie S. Czerwiński, J. Żukowska-Kalita, Usługowe prowadzenie ksiag on-line, [w:] Z. Fedak (red.), Rachunkowość Vademecum biur rachunkowych, wydanie specjalne, 2013, s. 125.

Współpraca między usługodawcą a usługobiorcą możliwa jest dzięki temu, iż zarówno biuro rachunkowe, jak i klient posiadają za pośrednictwem Internetu dostęp do baz danych księgowych z dowolnego miejsca, w czasie rzeczywistym. Klient może korzystać z danych w dwojaki sposób: biernie (tylko odczytując jej zawartość) lub czynnie (wprowadzając dane).

Bierne korzystanie $\mathrm{z}$ bazy danych polega na wglądzie $\mathrm{w}$ dane zapisane w księgach. Klient dostarcza dokumenty księgowe do biura rachunkowego, które dokonuje wszystkich czynności prowadzących do wygenerowania odpowiednich raportów i wyliczenia zaliczek na podatek. Forma ta jest bardzo zbliżona do tradycyjnej współpracy pomiędzy przedsiębiorstwem a usługodawcą - biurem rachunkowym. Zostaje podpisana umowa o świadczenie usług księgowo-podatkowych i outsourcer ponosi cywilną odpowiedzialność za swoje działania. Serwisy usług księgowo-podatkowych on-line dla przedsiębiorców biernie 
korzystających dedykowane są jednostkom prowadzącym księgowość zarówno w postaci ksiąg rachunkowych, jak i księgi przychodów i rozchodów, gdyż obsługą księgową zajmują się wykwalifikowani pracownicy usługodawcy.

Aktywne wykorzystanie bazy danych polega na użytkowaniu pewnych modułów oprogramowania (np. środki pieniężne, magazyn, fakturowanie, rozrachunki), udostępnionego klientowi do wprowadzania przez niego źródłowych dokumentów do systemu księgowego. Zbędne staje się podwójne wprowadzanie niektórych danych ${ }^{5}$, co pozwala zwiększyć efektywność pracy i daje realną obniżkę kosztów. Księgowość internetowa daje możliwość korzystania z szeregu opcji, które są przydatne przy prowadzeniu działalności gospodarczej. Poniżej przedstawiono poszczególne funkcjonalności, z jakich można korzystać w ramach usług księgowo-podatkowych świadczonych on-line:

1) dokumenty - w ramach aplikacji internetowej istnieje możliwość wystawienia dokumentów księgowych, takich jak: faktury, faktury pro forma, faktury zaliczkowej, rachunki, korekty, noty odsetkowe, a także dodanie innych przychodów;

2) koszty - wprowadzanie dokumentów zewnętrznych i bieżące monitorowanie kosztów ponoszonych przez przedsiębiorstwo;

3) baza klientów - można budować bazę klientów, dzięki czemu przy wystawianiu kolejnego dokumentu księgowego nie trzeba ponownie wprowadzać danych klienta. Jest to szczególnie przydatne przy stałej współpracy z danym kontrahentem, gdyż proces wystawiania dokumentów księgowych jest wtedy krótszy;

4) zatrudnienie - możliwość prowadzenia rejestru pracowników. Budowana może być lista płac, wystawiane umowy cywilno-prawne, a następnie generowane do nich rachunki;

5) deklaracje - można wygenerować najważniejsze deklaracje przydatne w prowadzeniu rozliczeń (PIT-5, VAT-7 oraz ZUS DRA). Nie ma potrzeby ich drukowania, osoby prowadzące bowiem serwisy księgowe udostępniają swoje podpisy elektroniczne w celu wysyłki deklaracji swoich klientów poprzez Internet;

6) terminarz - przedsiębiorca może umieścić w kalendarzu wszystkie prace, jakie musi wykonać, poza tym system przypomina $\mathrm{z}$ kilkudniowym wyprzedzeniem o płatnościach związanych z obciążeniami publiczno-prawnymi;

7) monitorowanie sprzedaży - przedsiębiorca może monitorować sprzedawane produkty, ich dostępność w magazynie, ceny. Aplikacja może też przypo-

\footnotetext{
${ }^{5} \mathrm{~W}$ tradycyjnym ujęciu - wystawianie faktury przez przedsiębiorcę, przekazanie jej w formie papierowej do osoby odpowiedzialnej za księgowość, następnie zaksięgowanie w systemie informatycznym. W przypadku świadczenia usług księgowo-podatkowych on-line ta sama faktura, wystawiona przez przedsiębiorcę zostanie automatycznie wprowadzona do systemu księgowego prowadzonego w biurze rachunkowym.
} 
minać o tym, że faktura na daną transakcję powinna być wystawiona w czasie 7 dni od momentu sprzedaży;

8) monitorowanie płatności - stałe monitorowanie rozliczenia wystawionych faktur;

9) analiza - osoba zarządzająca księgowością internetową ma możliwość obserwowania wykresów przychodów i kosztów, dzięki czemu na bieżąco monitoruje wyniki przedsiębiorstwa.

Aktywne korzystanie z systemu księgowego on-line umożliwia także kreowanie różnorodnych raportów indywidualnie dostosowanych do potrzeb klienta. Podstawową funkcją rachunkowości jest przecież dostarczanie szybkiej, aktualnej i syntetycznej informacji, co usprawni bieżące prosperowanie jednostki gospodarczej. Jednocześnie pozyskanie informacji dzięki technologii IT następuje w sposób jak najmniej czaso- i kapitałochłonny. Obecnie, w erze rewolucji informatycznej, gdy wiedza i informacja mają największą wartość, niezbędne jest zapewnienie zarządzającemu dostępu do potrzebnych mu danych w każdym miejscu i o dowolnej porze. Tworzenie raportów powinno odbywać się w na tyle zrozumiały sposób dla użytkownika, aby bez pośrednictwa księgowego lub informatyka mógł swobodnie uzyskać niezbędne dla siebie informacje ${ }^{6}$.

Zaletą usług księgowo-podatkowych on-line jest mobilność, ponieważ do korzystania z serwisu wystarczy jedynie dostęp do Internetu, a obsługa prowadzona jest $\mathrm{w}$ oknie przeglądarki internetowej. Nie ma potrzeby instalowania dodatkowego oprogramowania w komputerze. Założenie konta $\mathrm{w}$ serwisie księgowości internetowe zajmuje kilka chwil i jest równie proste jak rejestracja darmowego konta e-mail. Warunki korzystania z usług księgowo-podatkowych on-line uzależnione są od usługodawcy, który daną funkcjonalność udostępnia. By móc dokonywać poszczególnych operacji, należy zalogować się na stronie internetowej, korzystając ze wcześniej ustalonych w procesie rejestracji danych. Pierwszym krokiem, jaki należy wykonać przed rozpoczęciem wystawiania dokumentów księgowych przez Internet, jest wprowadzenie danych danej jednostki gospodarczej ${ }^{7}$. Dane te będą automatycznie umieszczane na poszczególnych dokumentach. Podstawowe operacje są intuicyjne i wspierane przez system multimedialnych prezentacji obrazujących krok po kroku działanie serwisu $^{8}$. Poza tym do dyspozycji klientów jest biuro obsługi udzielające porad z zakresu księgowości i podatków.

Usługi księgowo-podatkowe on-line pozwalają na generowanie elektronicznych wersji poszczególnych dokumentów ${ }^{9}$, a następnie ich zapisywanie na

${ }^{6}$ S. Czerwiński, J. Żukowska-Kalita, Ustugowe prowadzenie ksiag on-line, [w:] Z. Fedak (red.), Rachunkowość..., s. 125-126.

${ }_{8}^{7}$ Nazwa przedsiębiorstwa, dane teleadresowe, numer konta, NIP, REGON.

${ }^{8} \mathrm{Na}$ czym polega prowadzenie księgowości on-line, http://www.biznes-firma.pl (dostęp 26.03.2013).

${ }^{9} \mathrm{~Np}$. w formacie PDF. 
twardym dysku. Dzięki temu przedsiębiorstwo posiada elektroniczne kopie zapasowe wszystkich dokumentów, które zostały wystawione ${ }^{10}$. Ponadto, out-sourcer zapewnia bieżące archiwizowane danych, co pozwala łatwo odzyskać całą dokumentację $\mathrm{w}$ razie jej utraty lub zniszczenia. Ważnym problemem dotyczącym usług on-line jest bezpieczeństwo danych przechowywanych w serwisie księgowości, które gwarantuje:

- hasło użytkownika - zapewnia wyłączność dostępu do serwisu. Obsługa serwisu nie ma wglądu w dane zapisane na kontach użytkowników. Do wykonywania czynności służących rozwiązaniu problemów użytkowników, służy specjalny panel administracyjny;

- szyfrowanie - transmisja danych zabezpieczona jest 1024-bitowym certyfikatem SSL oraz szyfrowana 256-bitowym kluczem AES;

- kopie bezpieczeństwa - wykonywane są codziennie, szyfrowane i przechowywane w osobnych lokalizacjach. Dzięki temu dane nie zostaną utracone oraz nikt niepowołany nie powinien mieć do nich dostępu ${ }^{11}$.

Serwisy usług księgowo-podatkowych on-line dla przedsiębiorców aktywnie korzystających dedykowane są jednostkom prowadzącym księgowość w postaci Księgi Przychodów i Rozchodów i/lub będący płatnikami VAT. Usługa przeznaczona jest głównie dla mikroprzedsiębiorców, którzy nie dokonują złożonych operacji gospodarczych i posiadają niewielką ilość dokumentów księgowych $^{12}$.

Niewątpliwie minusem aktywnego korzystania z usług księgowo-podatkowych on-line jest brak odpowiedzialności usługodawcy, z jaką mamy do czynienia w przypadku tradycyjnych biur rachunkowych. Klient nie zawiera umowy na świadczenie usług księgowo-podatkowych, a jedynie akceptuje regulamin serwisu, który zakłada korzystanie z usług informatycznych.

\section{Studium przypadku firmy A Sp. z o.o.}

Firma A Sp. z o.o., założona w 2009 r. w Krakowie, prowadzi działalność usługową z zakresu obsługi księgowo-podatkowej on-line. Usługi te przeznaczone są dla freelancerów ${ }^{13}$, samozatrudnionych oraz mikro i małych przedsiębiorstw. Z serwisu spółki A korzysta obecnie 120 tys. jednostek gospodarczych.

\footnotetext{
${ }^{10}$ Księgowość internetowa w małej firmie, http://www.biznes-firma.pl (dostęp 27.03.2013).

${ }^{11}$ Firmy tna koszty i przechodza na e-Księgowość, http://finanse.wp.pl (dostęp 26.03.2013).

${ }^{12}$ e-Księgowość, http://internetdouslug.pl (dostęp 26.03.2013).

${ }^{13}$ Freelancer (pol. wolny strzelec) - osoba pracująca bez etatu, realizująca projekty na zlecenie, najczęściej specjalizująca się w danej dziedzinie. Do profesji szczególnie popularnych wśród wolnych strzelców należą: fotografia, dziennikarstwo, tłumaczenie, programowanie, malarstwo, grafika, doradztwo i inne zawody (głównie związane z pracą twórczą).
} 
Spółka posiada kapitał zakładowy w wysokości 126 tys. zł. Udziałowcami są dwie osoby fizyczne posiadające odpowiednio 69 i 26 udziałów oraz zagraniczny fundusz preferujący inwestowanie w Niemczech, Europie Wschodniej, Rosji, w takie dziedziny, jak: Internet, e-commerce czy firmy telefonów komórkowych, posiadający 46 udziałów. Zarówno prezes, jak i wiceprezes są to mężczyźni w wieku 29 lat, posiadający wykształcenie wyższe zdobyte m.in. na krakowskich uczelniach ekonomicznych oraz technicznych.

W 2011 r. firma A Sp. z o.o. otrzymała nagrodę Auler przyznawaną osobom i firmom będących wzorem dla polskiego biznesu technologicznego, ocenianym m.in. pod kątem innowacyjności, konsekwencji w rozwoju oraz promowania kultury przedsiębiorczości. „Bardzo cieszymy się z Aulera, jest on bowiem dowodem na to, że udaje nam się realizować wyznaczony cel, czyli dostarczać profesjonalne narzędzia do fakturowania i księgowości, oparte o rewelacyjne usability połączone z profesjonalną obsługą Klienta i doradztwem księgowych przez telefon, mail i chat. Naszym celem jest, aby spółka A był taką zmianą na rynku księgowości, jaką mBank stał się w bankowości. Dzisiaj bankowość internetowa jest standardem, a księgowość on-line jest podobną zmianą dla przedsiębiorców i przynosi podobne korzyści, zapewniając przedsiębiorcy oszczędność czasu, pieniędzy i świadomość finansów swojej firmy" - komentuje prezes firmy A Sp. z o.o.. Potwierdzeniem wysokiej jakości usług księgowych spółki A jest także członkostwo w Stowarzyszeniu Księgowych w Polsce. Firma A posiada Certyfikat Członka Wspierającego Stowarzyszenie Księgowych jako jedyna firma $\mathrm{z}$ branży księgowości on-line. Ponadto spółka A została wpisana przez stowarzyszenie na Listę Sygnatariuszy Kodeksu Zawodowej Etyki w Rachunkowości ${ }^{14}$.

Firma A Sp. z o.o. przez cały czas swojego istnienia prężnie się rozwija. W 2012 r. rozbudowała się zarówno w dziedzinie technologicznym, jak i zwiększyła liczbę pracowników z 12 do 32 osób. Uruchomiono trzy nowe stanowiska w firmie (Marketing Managera, HR Managera, User Experience Designera,). Przeprowadzono kilka płatnych staży w zakresie księgowości, programowania oraz marketingu.

Spółka A dostarcza usług w dwóch modułach: fakturowania oraz księgowości. Fakturowanie to aplikacja on-line do wystawiania faktur, które można wydrukować lub przesłać do klienta drogą mailową. Możliwość utworzenia listy klientów i szybkiego wyszukiwania ich według nazwy firmy, numeru NIP, nazwiska przedstawiciela lub numeru telefonu skraca czas wystawienia faktury. Pomaga w tym również baza najczęściej sprzedawanych towarów i usług. Program posiada opcję generowania raportów, takich jak ewidencja sprzedaży

${ }^{14}$ Tytuł poświadcza o rzetelnym i etycznym działaniu firmy lub jednostki. Zarówno certyfikat, jak i tytuł sygnatariusza są gwarancją jakości i etyki w branży księgowej. 
oraz dostęp do aplikacji dla wielu użytkowników jednocześnie. Aplikacja pozwala na sortowanie faktur według wszystkich parametrów. Posiada możliwość załączenia podpisu w formacie JPG, który zostanie wydrukowany na fakturze. Występuje także możliwość wystawiania faktur anglojęzycznych i polsko-angielskich, co może być szczególnie przydatne dla firm sprzedających swoje towary lub usługi za granicą. Program pozwala na zintegrowanie go $\mathrm{z}$ aplikacjami zewnętrznymi. $\mathrm{W}$ ten sposób proces wystawiania faktur umożliwia takie operacje, jak importowanie bazy klientów lub oferowanych produktów czy usług z programu zewnętrznego bezpośrednio do serwisu.

Rozwijając funkcjonalność fakturowania, spółka A buduje społeczną sieć biznesową, dostarczając użytkownikom aplikacji narzędzie pozwalające w łatwy i szybki sposób odbierać i zarządzać fakturami oraz monitorować koszty i płatności. Dzięki automatyzacji całego procesu wyeliminowane zostaje ręczne przepisywanie danych, co przekłada się na znaczną oszczędność czasu użytkownika. Oferowana usługa powoduje, że przedsiębiorca wystawiając fakturę w programie on-line, jednym kliknięciem myszki wprowadza ją do maila i przesyła kontrahentowi $\mathrm{w}$ formie PDF. Adresat faktury, po zaakceptowaniu funkcji importowania z poziomu maila, powoduje przeniesienie faktury do odpowiedniej zakładki w serwisie firmy A. Inną funkcją usługi jest automatyczny monitoring kosztów na poziomie terminów płatności.

Księgowość dostępna jest w dwóch wersjach aktywnego i biernego korzystania. Księgowość do aktywnego korzystania to rozwiązanie dla przedsiębiorców posiadających małą liczbę dokumentów i zwracających uwagę na cenę. Polega ona na samodzielnym prowadzeniu księgowości przy użyciu aplikacji on-line ze wsparciem księgowych przez telefon mail i live chat. Aktualnie aplikacja do prowadzenia księgowości on-line posiada następujące funkcjonalności:

- prowadzenie książki przychodów i rozchodów przedsiębiorstwa,

- oznaczanie statusu kosztów (zapłaconych, do zapłaty, niezapłaconych),

- generowanie rejestrów sprzedaży z dowolnego okresu według kwot lub statusów,

- generowanie raportów podatkowych w formacie PDF lub CSV (deklaracje PIT-5 oraz VAT-7),

- automatyczne powiadamianie o składkach ZUS do zapłacenia i generowanie danych do programu Płatnik,

- automatyczne powiadamianie o zaliczkach na podatki,

- automatyczna wymiana faktur między użytkownikami,

- automatyczne importowanie faktur z poziomu wiadomości e-mail.

Dodatkowo, dzięki możliwości zalogowania się do systemu z dowolnego miejsca, przedsiębiorca ma zapewniony elastyczny dostęp do danych księgowych i faktur, a prowadzenie księgowości jest tańsze niż obsługa przez 
tradycyjne biuro rachunkowe. Opłata za miesięczny dostęp do serwisu wynosi obecnie $29 \mathrm{zl}^{15}$.

Według firmy A Sp. z o.o. aplikacja stanowi jedynie wsparcie dla prowadzenia przez użytkownika działalności gospodarczej i tym samym usługodawca nie ponosi jakiekolwiek odpowiedzialności związanej z tak prowadzoną przez użytkownika działalnością gospodarczą. Usługodawca zastrzega, że korzystanie z serwisu odbywa się wyłącznie na koszt i ryzyko osoby go odwiedzającej. Przedsiębiorca zawiera ze spółką A umowę o świadczenie Ustugi Informacyjnej w momencie wprowadzenia do przeglądarki internetowej adresu URL serwisu, a rozwiązana $\mathrm{w}$ momencie zakończenia przeglądania stron serwisu. Umowa o świadczenie Ustugi Informatycznej zostaje zawarta na czas nieokreślony w przypadku korzystania $\mathrm{z}$ aplikacji z ramach wybranego pakietu, oraz na okres wynoszący według wyboru użytkownika: jeden miesiąc, jeden kwartał bądź jeden rok, od momentu pierwszego skorzystania.

Usługa księgowo-podatkowa do biernego korzystania polega na tym, iż to biuro rachunkowe prowadzi księgowość przedsiębiorstwa. Dokumenty odbierane są kurierem, a przedsiębiorca ma dostęp do wszystkich dokumentów firmy przez aplikację on-line. Dodatkowo spółka A reprezentuje przedsiębiorcę w kontaktach z US i ZUS, a także ponosi odpowiedzialność za swoje usługi. Usługa jest konkurencyjna cenowo w stosunku do tradycyjnych biur rachunkowych - miesięczny koszt obsługi to $199 \mathrm{zl}^{16}$. Idea usługi jest następująca - każdego 5-tego dnia miesiąca kurier zabiera dokumenty przedsiębiorcy i przekazuje je do firmy A, gdzie są one skanowane, rozliczane i wprowadzane do profilu użytkownika. Przedsiębiorca otrzymuje mailowe powiadomienie o wysokości składek ZUS i podatków do zapłacenia. Najważniejszą jednak cechą księgowości do biernego korzystania jest umożliwienie przedsiębiorcy wglądu w aktualne dane finansowe firmy. Kiedy pojawia się konieczność wyszukania faktury, bez jeżdżenia do biura rachunkowego i wyszukiwania dokumentów w segregatorach, przedsiębiorca może szybko odnaleźć w aplikacji właściwy dokument. W przypadku ewentualnych pytań użytkownik może korzystać z konsultacji księgowych dostępnych od poniedziałku do piątku w godz. 7.00$22.00 \mathrm{i}$ w soboty od godz. 9.00 do 17.00 - czyli prawie dwukrotnie dłużej niż tradycyjne biura rachunkowe. Jednak trzymiesięczna współpraca ze spółką A pozwoliła wyciągnąć wnioski, iż porady udzielana za pomocą poczty elektronicznej sprowadzają się bardziej do pomocy technicznej związanej z obsługą serwisu, niż rozwiązywania problemów merytorycznych. Usługa całkowicie eliminuje konieczność osobistego pojawiania się w biurze, ponieważ nawet podpisanie umowy odbywa się w siedzibie usługobiorcy.

\footnotetext{
${ }^{15}$ Cennik z 04.05.2013 r.

${ }^{16}$ Cennik z 04.05.2013 r.
} 
Ponadto firma A Sp. z o.o. jako jedyny dostawca usług księgowych w Polsce oferuje aplikacje mobilne na iPhone'a oraz Androida. Pierwszym wyzwaniem, jakie zostało rzucone tradycyjnej księgowości, była aplikacja do fakturowania i księgowości on-line, pozwalająca przedsiębiorcom samodzielnie prowadzić swoją księgowość. Potem pracowaliśmy nad księgowością do biernego korzystania, którą definiujemy jako święty spokój przedsiębiorcy, bo księgowością zajmuje się biuro rachunkowe firmy A, kurier odbiera dokumenty, a wystawianie faktur i wgląd we wszystkie dane odbywa się za pomocą aplikacji on-line. Kolejnym elementem wyróżniającym nas spośród konkurencji jest A MOBILE, czyli aplikacja A na iPhone'a i telefony z Androidem, dzięki czemu każdy przedsiębiorca ma dostęp do danych swojej firmy w dowolnym momencie i może wystawić fakturę bez używania komputera - mówi prezes spółki A. A MOBILE odpowiada ogólnemu trendowi rozwoju aplikacji mobilnych, popularnych ze względu na wygodę ich stosowania, ale także ze względu na wymierne korzyści, jakie przynoszą przedsiębiorcy. Dostęp do aplikacji z poziomu urządzenia mobilnego pozwala już w trakcie spotkania $\mathrm{z}$ klientem lub zaraz po jego zakończeniu wystawić oraz przesłać fakturę, a także umożliwia szybki dostęp do danych księgowych, co stanowi doskonałe uzupełnienie wersji internetowej. Dzięki synchronizacji komputera z urządzeniem mobilnym wystawione $\mathrm{z}$ poziomu telefonu lub komputera dokumenty są na bieżąco rejestrowane na koncie użytkownika, gwarantując zachowanie płynności w prowadzeniu przedsiębiorstwa oraz spójność w dokumentacji.

Właściciele spółki A deklarują, iż wszystkie dane wykorzystywane w obsłudze serwisu znajdują się pod ścisłą ochroną. Przechowywane są na dedykowanych serwerach niemieckiego dostawcy firmy Hetzner, gdzie tworzone są ich kopie zapasowe, a 24-godzinny monitoring chroni przed niepowołanym dostępem do danych. Za ich bezpieczeństwo odpowiadają także m.in. szyfrowane połączenie SSL oraz systemy Firewall.

Założyciele spółki A, tworząc swoje usługi, założyli, iż na arenę przedsiębiorczości wchodzi generacja Y, która aktywnie i w każdej dziedzinie życia korzysta z nowoczesnych technologii. Są to ludzie z dużą pewnością siebie, otwarci na nowości. Lubią samodzielnie zarządzać swoim czasem. Świadomie rezygnują z etatu na rzecz prowadzenia własnej działalności. To właśnie przede wszystkich z myślą o nich powstała księgowość on-line. Mając powyższe na uwadze, twórcy firmy A Sp. z o.o. mają ambitne cele, gdyż chcą w ciągu kolejnych 2 lat zdobyć 4\% rynku księgowości w Polsce oraz osiągać przychody bliskie $30 \mathrm{mln}$ zł pod koniec $2014 \mathrm{r}$. 


\section{Zakończenie}

Usługi księgowo-podatkowych on-line łączą w sobie korzyści, jakie daje prowadzenie księgowości we własnym zakresie (posiadanie bieżącej informacji), a zarazem zalety usługowego prowadzenia ksiąg, gdyż nie występują problemy związane z zatrudnieniem wyspecjalizowanego pracownika. O tym, że księgowość on-line zdobywa coraz większe zainteresowanie wśród przedsiębiorców, decyduje wygoda użytkowania narzędzi księgowych w Internecie. E-księgowość pozwala użytkownikom na samodzielne prowadzenie dokumentacji przedsiębiorstwa za pośrednictwem sieci www. Nie bez znaczenia dla popularyzacji księgowości elektronicznej jest oszczędność czasu przedsiębiorcy. Wygoda zastosowania księgowości on-line skłania klientów do zakładania kont w serwisach, które taką usługę oferują. Zaletą księgowości on-line jest także jej cena - niższa niż koszty zatrudnienia księgowej czy biura rachunkowego w ramach outsourcingu ${ }^{17}$. Należy mieć jednak na uwadze, iż korzystając aktywnie z usług księgowo-podatkowych on-line cała odpowiedzialność za działania w tym zakresie spoczywa na usługobiorcy.

Wychodząc naprzeciw oczekiwaniom usługobiorcy, powstaje w Polsce wiele jednostek gospodarczych zajmujących się usługami księgowo-podatkowymi on-line. Jednym $\mathrm{z}$ takich podmiotów jest prężnie rozwijające się przedsiębiorstwo z Krakowa założone przez dwóch młodych biznesmenów. Outsourcer ten ma bogatą ofertę świadczonych usług, a co za tym idzie powiększającą się z roku na rok liczbę klientów.

\section{Literatura}

Budzik K., Metody badań empirycznych, [w:] Strzyżewska M. (red.), Doktoranci o przygotowaniu konspektu pracy doktorskiej, Szkoła Główna Handlowa Oficyna Wydawnicza, Warszawa 2007.

Czarecki J., Przesłanki korzystania z zewnętrznych ustug księgowych przez mikro i małe przedsiębiorstwa z Województwa Lubelskiego, [w:] Bielawska A. (red.), Uwarunkowania rynkowe rozwoju mikro i matych przedsiębiorstw Mikrofirma 2009, Wydawnictwo Uniwersytetu Szczecińskiego, Szczecin 2009.

Czerwiński S., Żukowska-Kalita J., Ustugowe prowadzenie ksiag on-line, [w:] Fedak Z. (red.), Rachunkowość Vademecum biur rachunkowych, wydanie specjalne, 2013.

e-Księgowość, http://internetdouslug.pl.

Firmy tna koszty i przechodza na e-Księgowość, http://finanse.wp.pl.

Ksiegowość internetowa w małej firmie, http://www.biznes-firma.pl.

Ksiegowość on-line zyskuje na popularności http://mybankier.com.

${ }^{17} \mathrm{Na}$ czym polega prowadzenie księgowości on-line, http://www.biznes-firma.pl (dostęp 26.03.2013). 
Mesure H., Spigarelii F., Studia przypadków internacjonalizacji matych i średnich przedsiębiorstw we Francji i Włoszech, [w:] Dominicka P., Wasilczuk J., Daszkiewicz N. (red.), Małe i średnie przedsiębiorstwa $w$ obliczu internacjonalizacji i integracji gospodarek europejskich Przykłady Włoch, Francji, Polski i Czech, Scintific Publishing Group, Gdańsk 2005.

Na czym polega prowadzenie księgowości on-line, http://www.biznes-firma.pl.

Zaborek P., Studium przypadku jako metoda badawcza, [w:] Strzyżewska M. (red.), Doktoranci o przygotowaniu konspektu pracy doktorskiej, Szkoła Główna Handlowa Oficyna Wydawnicza, Warszawa 2007.

\section{Streszczenie}

Usługi księgowo-podatkowe on-line to nowoczesny sposób usługowego prowadzenia ksiąg podatkowych, który umożliwia przetwarzanie danych księgowych obejmujący całość prac ewidencyjnych. Polega na udostępnieniu klientowi przez usługodawcę systemu informatycznego, pomocy specjalistów oraz wiedzy merytorycznej dla bieżącej realizacji potrzeb w zakresie ewidencji oraz informacji księgowo-podatkowej.

W celu skonfrontowania wiedzy teoretycznej i praktyki autorka wykorzystała popularną metodę badawczą jaką jest studium przypadku, by zilustrować jednostkę gospodarczą, która zajmuje się usługami on-line z zakresu księgowości.

\section{Summary}

\section{ON-LINE ACCOUNTING TAX SERVICES AS AN ALTERNATIVE TO TRADITIONAL ACCOUNTING OFFICE}

Financial on-line services are a modern way of keeping the tax, which allows the processing of accounting data covering the entire work of registration. These services rely on the availability of the customer by the service provider system, support specialists and technical knowledge for the current realization of the need to register as well as accounting and tax information.

In order to confront the theoretical and practical knowledge the author has used a popular research method that is the case study to illustrate the entity that deals with on-line services in the field of accounting. 